\title{
Production and Characterization of Polyhydroxybutarate from Halophilic Bacteria
}

\author{
Vinod P. S ${ }^{1}$, Deepali S. Kulkarni², M. B. Sulochana ${ }^{1}$ \\ ${ }^{1}$ Department of Biotechnology, Gulbarga University, Kalaburagi, Karnataka, India \\ ${ }^{2}$ Department of Biotechnology, Walchand College of arts and science, Solapur, Maharashtra, India
}

\begin{abstract}
Halophilic microorganisms thrive at elevated concentrations of sodium chloride up to saturation and are capable of growing on a wide variety of carbon sources. Hence, the biotechnological application of these microorganisms can cover many aspects one of these is bioplastic production. Biodegradable plastics are plastics that are decomposed by the action of living organisms using bacteria. Biodegradable plastic is a renewable biopolymers synthesized in bacteria having similar characteristics of plastics produced from petroleum character. In the following work preisolated halophilic strains were screened for PHB production. The positive strains were subjected to PHB production. Estimation of PHB was done by using UV spectrophotometer and FTIR. Highest PHB producing strain was further used for optimization of different parameters for PHB production.
\end{abstract}

Keywords : Halophiles, Polyhydroxybutyrate, Bioplastic, Nile blue, Biomedical.

\section{INTRODUCTION}

Halophiles are organisms that thrive in high salt concentrations. They are a type of extremophile organisms. Halophiles can be found anywhere with a concentration of salt five times greater than the salt concentration of the ocean. The amount of plastic waste increases every year and the exact time needed for its biodegradation is unknown. Nowadays plastic and synthetic Polymers are mainly produced using petrochemical material that cannot be decomposed. Therefore, they contribute to environmental pollution and are a danger to many animals. During the last decade much attention has been focused on the production of bacteria polyester. Bioplastics are made from compound called as polyhydroxyalkanoate (PHA). The family of polyhydroxyalkanoate include several polymeric esters such as PHB, PHV, PHH. Poly3- hydroxybutyric acid (PHB) is the most common natural microbial PHA. Different bacterial types of microorganisms produce $\mathrm{PHB}$ from renewable sources from sugar and molasses as intracellular storage materials.

Microbial bioplastics are polyester that are produced by a range of microorganisms cultivated under various growth and nutrient conditions. This polymer accumulate as a strong material such as mobile, amorphous, lipid granual meant for microbial survival under stressful conditions (Ningthoujam, 2009). Bacterial plastic is usually defined as an existing new area of research,where naturally synthesized bacterial polymer as, lipid storage material. PHB is being used as raw materials for plastic based packaging materials (Madigan et.al.,1997). 
Microorganisms transform sugars and fatty acids to PHAs through metabolic pathways that involve as intermediate either acetyl-CoA or acyl-CoA and conclude with monomer polymerization by PHA synthases (Philip et al. 2007). Poly(3hydroxybutyrate) (PHB) is the most common type of the PHAs synthesized by microorganisms and is rigid and brittle (Steinbüchel and Füchtenbush 1998; Philip et al. 2007). However, copolymers with varying monomer compositions can also be produced resulting in a high diversity of PHA molecules possessing a broad range of physico-chemical and mechanical properties, for example, poly(3hydroxybutyrate-co-hydroxyvalerate) (PHBV) that is a more flexible material than PHB (Steinbüchel and Füchtenbush 1998; Philip et al. 2007). PHAs are also biocompatible and lack toxicity (Philip et al. 2007). Owning to this features, PHAs have been used to develop some devices for medical applications including biodegradable sutures, meniscus repair devices, bone plates, heart valves, nerve conduits, and drug delivery systems (Chen and Wu 2005; Wu et al. 2009).

\section{MATERIALS AND METHODS}

\section{Sub culturing of preisolated strains}

The pure culture of pre- isolated strains were collected from western coastal regions of Karwar. The strains were subcultured on the slants containing the selective halophilic medium (HM medium) containing $2 \%$ agar with $10 \% \mathrm{NaCl}$. The inoculated tubes were incubated at $37 \pm 2^{\circ} \mathrm{C}$ for $48-72$ hours. The slants were preserved at $4{ }^{\circ} \mathrm{C}$ for further studies.

Table 1 : The composition of HM media

\begin{tabular}{|l|l|l|}
\hline Sr. No. & Component & Amount \\
\hline 1 & Peptone & $10(\mathrm{~g} / \mathrm{L})$ \\
\hline 2 & Yeast extract & $10(\mathrm{~g} / \mathrm{L})$ \\
\hline 3 & Trisodium citrate & $3(\mathrm{~g} / \mathrm{L})$ \\
\hline
\end{tabular}

\begin{tabular}{|l|l|l|}
\hline 4 & $\mathrm{KCl}$ & $2(\mathrm{~g} / \mathrm{L})$ \\
\hline 5 & $\mathrm{MgSO}_{4} .7 \mathrm{H}_{2} \mathrm{O}$ & $20(\mathrm{~g} / \mathrm{L})$ \\
\hline 6 & $\mathrm{FeCl}_{2}$ & $0.023(\mathrm{~g} / \mathrm{L})$ \\
\hline 7 & $\mathrm{NaCl}$ & $100(\mathrm{~g} / \mathrm{L})$ \\
\hline 8 & Agar agar & $20(\mathrm{~g} / \mathrm{L})$ \\
\hline 9 & $\mathrm{D} / \mathrm{W}$ & $1000 \mathrm{ml}$ \\
\hline
\end{tabular}

$\mathrm{pH} 7.0 \pm 0.2$ at $25^{\circ} \mathrm{C}$

\section{Nile blue A screening}

Poly-betahydroxybutyrate granules exhibited a strong orange fluorescence when stained with Nile blue A. Nile blue A solution was prepared in DMSO. The HM media was prepared and sterilized at $121^{\circ} \mathrm{C}$ for $15 \mathrm{~min}$ at $15 \mathrm{lbs}$ pressure. After sterilization the Nile blue A solution was added to sterile HM agar medium. The plates were prepared and each strain was incubated at $37{ }^{\circ} \mathrm{C}$ for 48 hours on it. The agar plates were exposed to UV lightto detect $\mathrm{PHB}$ accumulation in grown colonies.

\section{Production of PHB}

Table 2 : Media used for production of PHB

\begin{tabular}{|l|l|l|}
\hline Sr. no. & Composition & Amount \\
\hline 1 & Nacl & $20.0 \mathrm{~g}$ \\
\hline 2 & $\mathrm{MgSO} 4.7 \mathrm{H} 2 \mathrm{O}$ & $10.0 \mathrm{~g}$ \\
\hline 3 & $\mathrm{KCl}$ & $5.0 \mathrm{~g}$ \\
\hline 4 & Tryptone & $2.5 \mathrm{~g}$ \\
\hline 5 & Yeast extract & $10.0 \mathrm{~g}$ \\
\hline 6 & $\mathrm{CaCl}_{2} .6 \mathrm{H}_{2} \mathrm{O}$ & $0.2 \mathrm{~g}$ \\
\hline 7 & Agar & $20.0 \mathrm{~g}$ \\
\hline 8 & Distilled water & $1000 \mathrm{ml}$ \\
\hline \multicolumn{3}{|c|}{$\mathrm{pH} 7 \pm 0.2$ at $25^{\circ} \mathrm{C}$} \\
\hline
\end{tabular}

Among the ten strains those were stained positive were selected for comparative production of PHB. The strains were inoculated in the sterile production medium and were incubated for 96 hours at $25^{\circ} \mathrm{C}$ on rotary shaker.

\section{Extraction of Poly- $\beta$-hydroxybutyrate produced}


PHB produced from the selected strains were extracted by the following procedure. About $10 \mathrm{ml}$ of Bacterial culture (96 hours) was taken and centrifuged at $10000 \mathrm{rpm}$ for 10 minutes. The supernatant was discarded and the pellet was suspended with $2.5 \mathrm{ml}$ of $10 \% \mathrm{NaCl}$ and centrifuged at $10000 \mathrm{rpm}$ for $10 \mathrm{minutes}$. Take the pellet and add $2.5 \mathrm{ml}$ chloroform (Law,Slepecky et al,1961).The pellet suspension was incubated at $60^{\circ} \mathrm{C}$ for 15 minutes. After incubation, the suspension was centrifuged at 10000rpm for 10minutes. Add 10\% Sulphuric acid in equal volume, centrifuge added to the tube and kept in boiling water bath for 10min for the conversion of PHB into crotonic acid. After cooling the absorbance was measured at 210 to 290nm using UV spectrophotometer and graph was plotted. About $2 \mathrm{ml}$ of concentrated sulphuric acid was used as blank.

\section{Estimation of Poly $-\beta$ - hydroxybutarate \\ Estimation using UV spectrophotometer}

About 2mg of extracted PHB was added in $2 \mathrm{ml}$ of concentrated sulphuric acid added to the tube and kept in boiling water bath for $10 \mathrm{~min}$ for the conversion of PHB into crotonic acid. After cooling the absorbance was measured at 210 to $290 \mathrm{~nm}$ using UV spectrophotometer and graph was plotted. About $2 \mathrm{ml}$ of concentrated sulphuric acid was used as blank.

\section{Characterization by using FTIR (Fourier Transform Infra-Red Analysis)}

The chloroform phase containing PHB was subjected to FTIR Spectroscopy analysis. In order to know the functional groups present in PHB, $1 \mathrm{mg}$ of extracted sample of PHB was dissolved in $5 \mathrm{ml}$ of chloroform. The chloroform was allowed to evaporate to get PHB powder, which was subjected to FTIR analysis using FTIR spectrophotometer. Spectra were recorded in $4000 \mathrm{~cm}^{-1}$ to $600 \mathrm{~cm}^{-1}$ range. (Naumann et al.,1991).

\section{Effect of $\mathrm{NaCl}$ on growth and production of $\mathrm{PHB}$}

The effect of $\mathrm{NaCl}$ was studied on growth and $\mathrm{PHB}$ production using production medium (halobacterium medium) containing different concentration of $\mathrm{NaCl}$ $(5,10,15,20$ and 25\%w/v) inoculated broth were kept under shaker at temperature $25 \pm 2{ }^{\circ} \mathrm{C}$ and $\mathrm{pH} 7$.

\section{Optimization of time for the production of PHB}

In order to optimize the time for the production of $\mathrm{PHB}$, the bacterial cultures were inoculated in production medium $(\mathrm{pH})$ and incubated at temperature $25 \pm 2 \circ \mathrm{C}$ for various time duration (48, 72 , 96 and 120 hours). All the cultures were incubated under standardized condition for optimisation of time. After incubation, the broth cultures were subjected to PHB extracted method and in each trial, the production rate of $\mathrm{PHB}$ was compared to standard PHB.

Optimization of temperature for the production of PHB

In order to optimize the temperature for the production of $\mathrm{PHB}$, the bacterial culture was inoculated in minimal broth $(\mathrm{pH} 7)$ and incubated at temperature $30^{\circ} \mathrm{C}, 37 \circ \mathrm{C}$, and $45^{\circ} \mathrm{C}$ for 48 hours. All the cultures were incubated under standardized condition for optimisation of temperature. After incubation, the broth cultures were subjected to PHB extraction by crotonic acid method and in each trial, the production rate of $\mathrm{PHB}$ was compared to standard PHB.

\section{RESULTS AND DISCUSSION}

\section{Sub culturing of preisolated halophilic strains}

The pure preisolated strains of halophilic bacteria isolated from west coastal regions of Karwar were subcultured on the HM medium at $\mathrm{pH} 7$ with $10 \%$ $\mathrm{NaCl}$ concentration. The strains were stored at $4{ }^{\circ} \mathrm{C}$ for further studies. The details of strains are as shown in table no. 3 and figure no. 1.

\section{Optimization of growth parameters}

Nile blue A screening 
Screening of all 10 strains by Nile Blue A stain was done. The PHB granules exhibited a strong orange fluorescence under UV light. Three strains showed presence of PHB granules. The details of Nile Blue screening is as shown in table no.4. Similar studies for detection of PHB producing bacteria by using Nile blue A dye by Nidhi Patel et al.,2017. The PHB accumulating colonies showed bright brownish black, shiny white, orange or yellow colour colonies after exposing under UV light. In similar study Alejandra Rodriguez-Contreraset. et.al., also observed bright orange colour Colonies under UV light.

\section{Production of PHB}

The production of PHB using three positive strains was carried out by using PHB production media for Halophiles. PHB media containing $2 \% \mathrm{NaCl}$ concentration, $1 \%$ peptone, $0.25 \%$ tryptone, $0.5 \% \mathrm{KCl}$, $1 \% \mathrm{MgSO} 4.7 \mathrm{H} 2 \mathrm{O}$. The media was incubated at $25^{\circ} \mathrm{C}$ with $\mathrm{pH} 7$ for 96 hours. The fermentation media after the incubation period is shown in figure 2. The fermented broth was then applied for extraction of PHB.

Table 3: List of pure preisolated Halophilic strains

\begin{tabular}{|l|l|l|l|}
\hline $\begin{array}{l}\text { Sr } \\
\text { no }\end{array}$ & $\begin{array}{l}\text { Code } \\
\text { names }\end{array}$ & Organisms & $\begin{array}{l}\text { Gen Bank } \\
\text { Accession } \\
\text { Number }\end{array}$ \\
\hline 1 & 3 KB2 & $\begin{array}{l}\text { Oceanobacill } \\
\text { us sp }\end{array}$ & JX104224 \\
\hline 2 & JM3 & $\begin{array}{l}\text { Salinicoccus } \\
\text { roseus }\end{array}$ & HQ704873 \\
\hline 3 & JN12 & $\begin{array}{l}\text { Salinicoccus } \\
\text { sp }\end{array}$ & HQ426914 \\
\hline 4 & KS22 & $\begin{array}{l}\text { Halobacillus } \\
\text { sp }\end{array}$ & - \\
\hline 5 & JKG6 & $\begin{array}{l}\text { Oceanobacill } \\
\text { us sp }\end{array}$ & HQ186237 \\
\hline 6 & KS3 & $\begin{array}{l}\text { Virgibacillus } \\
\text { sp }\end{array}$ & KU248096 \\
\hline 7 & JG8 & $\begin{array}{l}\text { Virgibacillus } \\
\text { sp }\end{array}$ & KU248097 \\
\hline
\end{tabular}

\begin{tabular}{|l|l|l|l|}
\hline 8 & JKG1 & - & - \\
\hline 9 & $3 \mathrm{~KB} 1$ & - & - \\
\hline 10 & $1 \mathrm{KG} 1$ & - & - \\
\hline
\end{tabular}

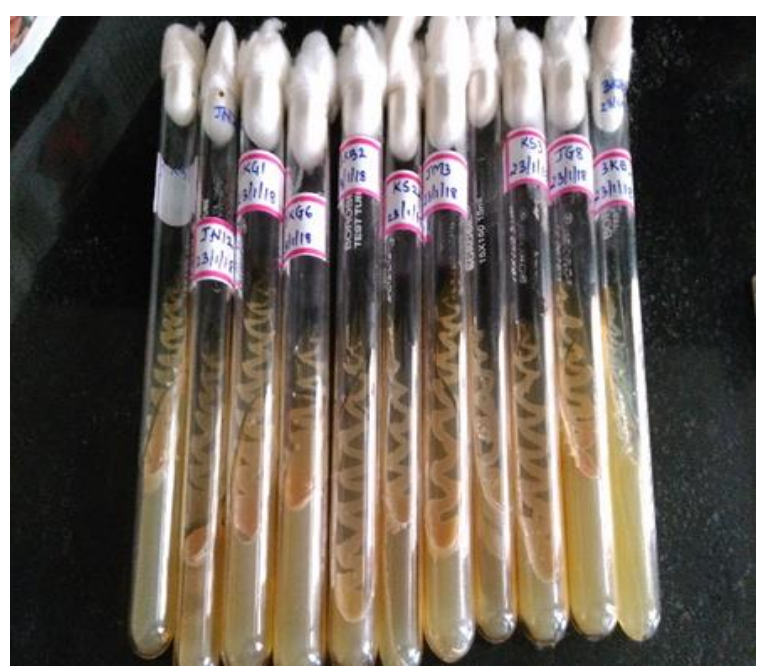

Fig. 1 : Subcultures of preisolated strains

Table 4: Nile Blue A screening

\begin{tabular}{|c|c|c|}
\hline Sr. no & Code names & $\begin{array}{c}\text { Staining of PHB } \\
\text { granules }\end{array}$ \\
\hline 1 & 3 KB2 & Negative \\
\hline 2 & JM3 & Negative \\
\hline 3 & JN12 & Positive \\
\hline 4 & KS22 & Positive \\
\hline 5 & JKG6 & Positive \\
\hline 6 & KS3 & Negative \\
\hline 7 & JG8 & Negative \\
\hline 8 & JKG1 & Negative \\
\hline 9 & $3 K B 1$ & Negative \\
\hline 10 & 1KG1 & Negative \\
\hline
\end{tabular}

\section{Extraction of Poly- $\beta$-hydroxybutyrate produced}

The extraction of PHB was done by chloroform extraction method. The bacterial culture after incubation was centrifuged and the pellet was treated $10 \%$ Nacl. Centrifugation was carried out and the pellet was treated with chloroform. After incubation at $60^{\circ} \mathrm{C}$ the suspention was centrifuged and treated with 10\%sulphuric acid. After 
centrifugation the PHB granules were precipitated by using methanol. The powdered form of PHB was extracted by drying for 2 hours in oven. The dried PHB powder was weighed.Among the three strains KS22 showed 32mg/lit PHB production, JKG6 showed 12mg/lit of PHB while JN12 strain showed 38mg/lit of PHB production.As shown in figure 3. Since JN12 showed highest PHB production it was used for further process.

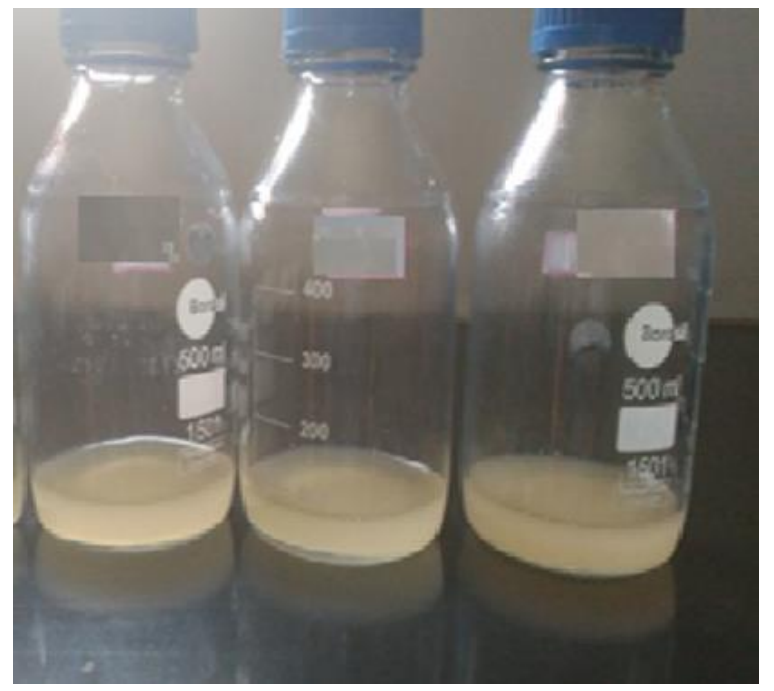

Fig. 2 : Production of PHB by selected strains

\section{Analysis of Poly - $\beta$ - hydroxybutarate}

\section{Estimation using UV spectrophotometer}

The crotonic acid produced by dissolving PHB in sulphuric acid was subjected to UV spectrophotometer with sulphuric acid as blank. At $230 \mathrm{~nm}$ the highest OD was recorded as shown in figure 4. This estimated that extracted product was PHB as PHB shows highest absorbance at $230 \mathrm{~nm}$ (Khanafariet.al., 2006)

\section{Characterization by using FTIR (Fourier Transform Infra-Red Analysis)}

The PHB was analysed by FTIR in order to known the functional groups present in the chemical structure of PHB at molecular level, taken as standard reference. The characteristic peaks at $1044.38 \mathrm{~cm}-1$, $1454.38 \mathrm{~cm}-1$ and $1743.77 \mathrm{~cm}-1$ corresponds to the
$\mathrm{C}-\mathrm{O}, \mathrm{C}-\mathrm{H}$ and $\mathrm{C}=\mathrm{O}$ shows the functional groups present in the structure of pure PHB (Figure 5 ).

\section{Optimization of growth parameters}

Optimization for PHB production is an important task, which favours the microbes to enjoy in eating the substrates without any disturbances. For optimization of $\mathrm{PHB}$ production, a change in particular constituents such as $\mathrm{NaCl}$, temperature, time duration required were used and the results are discussed as follows.

\section{Effect of $\mathrm{NaCl}$ on growth and production of $\mathrm{PHB}$}

The effect of $\mathrm{NaCl}$ was studied on growth and production of $\mathrm{PHB}$ at various $\mathrm{NaCl}$ concentrations. The growth and PHB production was observed from $5-25 \%$ of $\mathrm{NaCl}$. The methanol precipitation of PHB at different $\mathrm{NaCl}$ concentration is shown in the figure 6 . $5 \% \mathrm{NaCl}$ was found to be optimum for the production of PHB. As shown in the figure 7 . Halomonas sp. exhibited substantially different properties, among them the requirement for high salt concentration for activity and stability is due to the excess of acidic amino acid present in them (Mevarech, et al., 2000).

\section{Optimization of time for the production of PHB}

In order to optimize the time for the production of $\mathrm{PHB}$, the bacterial cultures were inoculated in minimal broth ( $\mathrm{pH} \mathrm{7)}$ and incubated for 48, 72, 96 and 120 hours. All the isolates were incubated under standardised conditions for optimization of time. After incubation, the broth culture was subjected to PHB extraction by method and in each trial, the production rate of $\mathrm{PHB}$ was compared with standard PHB. 48hours was found to be optimum time for production of $\mathrm{PHB}$ as shown in figure 8 .

\section{Optimization of temperature for the production of PHB}

In order to optimize the temperature for the production of $\mathrm{PHB}$, the bacterial cultures were inoculated in minimal broth $(\mathrm{pH} 7)$ and incubated at 
temperature $30^{\circ} \mathrm{C}, 37^{\circ} \mathrm{C}$ and $45^{\circ} \mathrm{C}$ for 48 hours. All the isolates were incubated under standardised conditions for optimization of temperature. After incubation, the broth culture was subjected to $\mathrm{PHB}$ extraction by crotonic acid method and in each trial, the production rate of $\mathrm{PHB}$ was compared with standard PHB. $39^{\circ} \mathrm{C}$ temperature was observed to be optimum temperature for PHB production, as shown in figure 9.

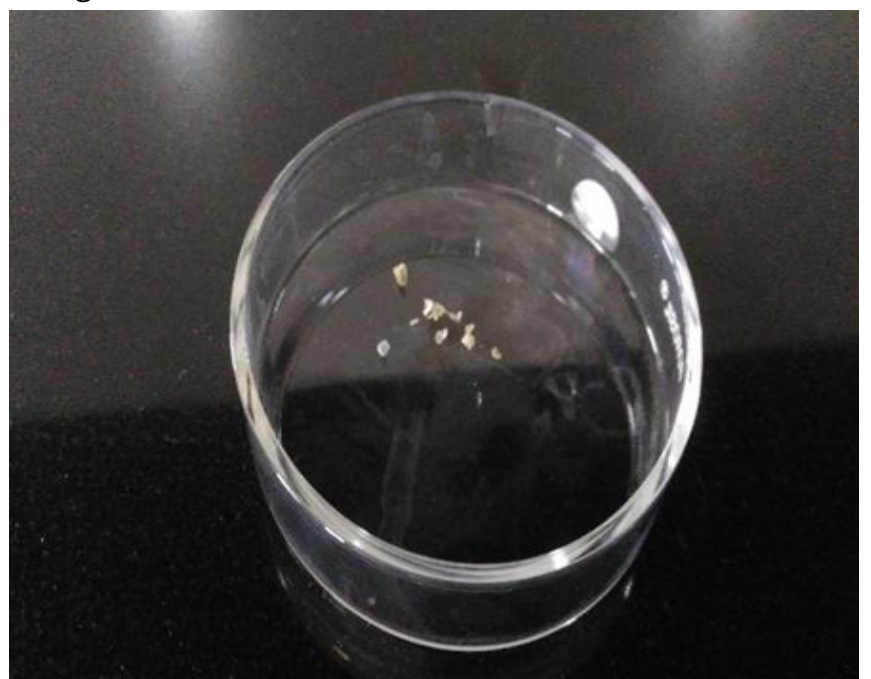

Fig. 3 :Extracted PHB

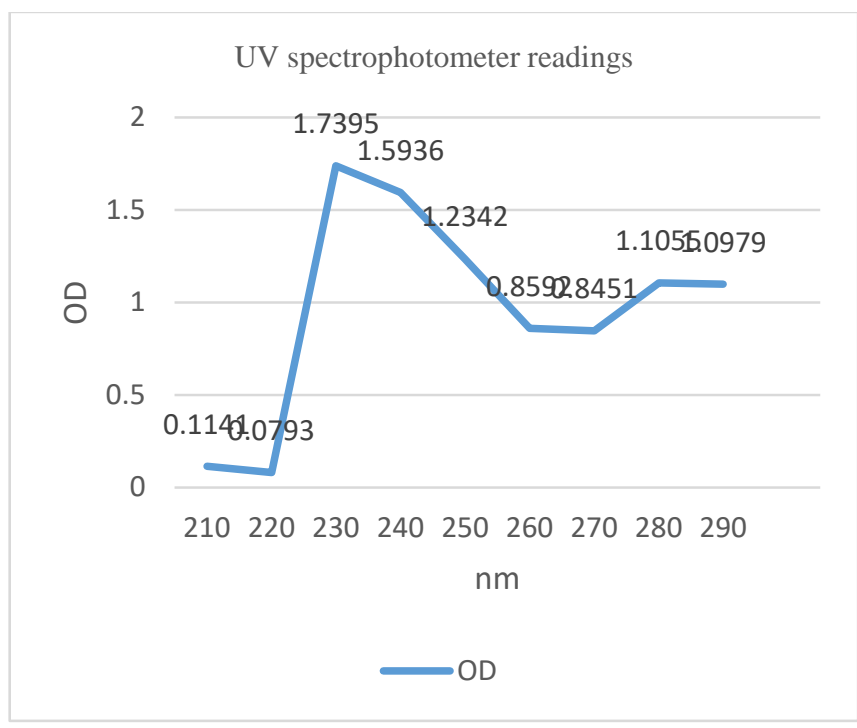

Fig. 4 :Estimation of PHB using UV spectrophotometer

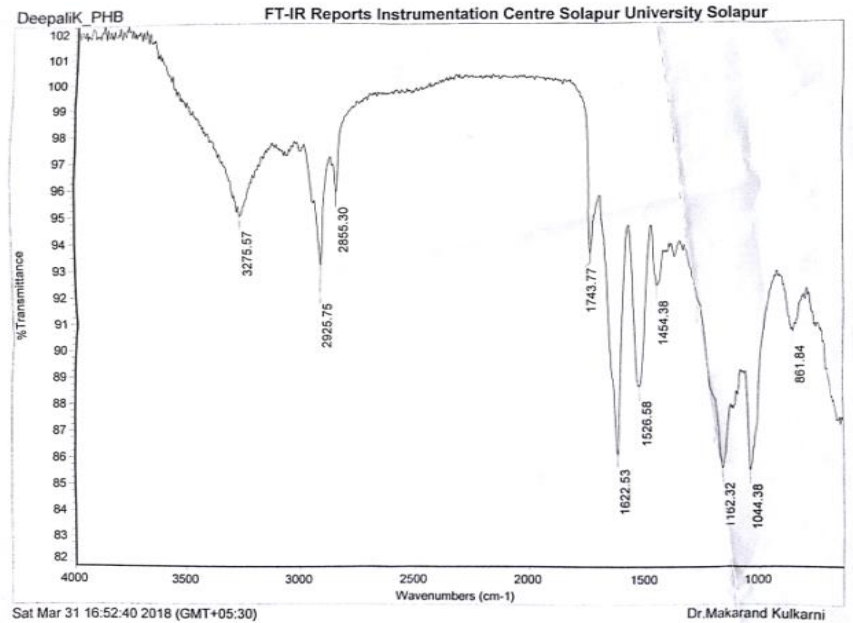

Fig. 5 : Analysis \& characterization of PHB by FTIR

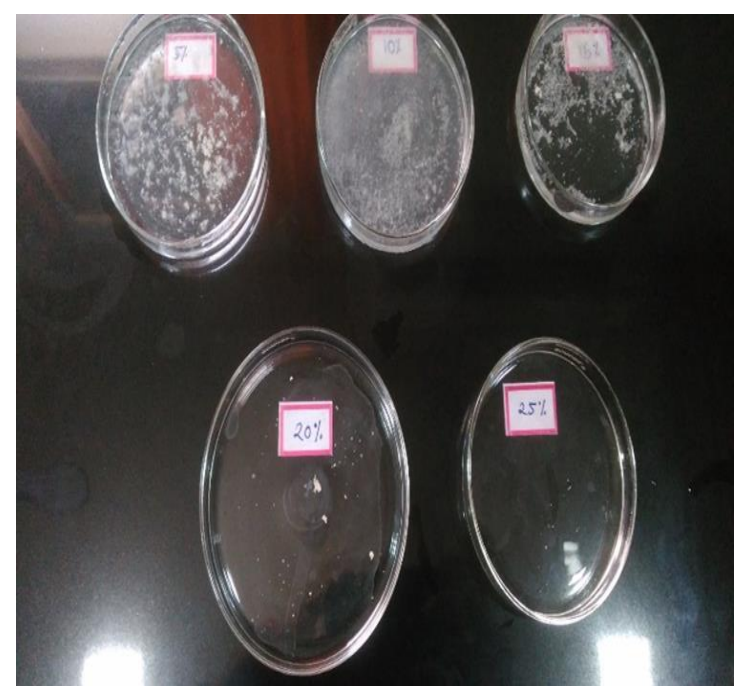

Fig. 6 : Extracted $\mathrm{PHB}$ at different $\mathrm{NaCl}$ concentration

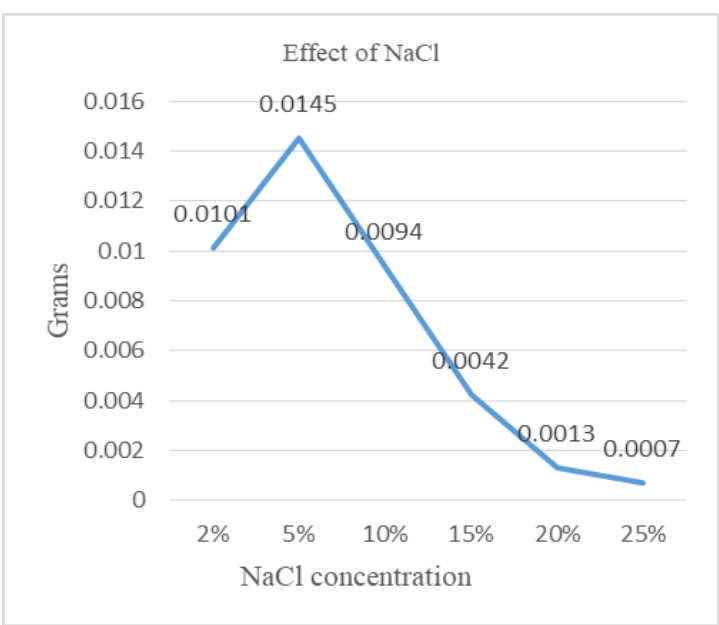

Fig. 7 : Effect of $\mathrm{NaCl}$ on production of $\mathrm{PHB}$ 


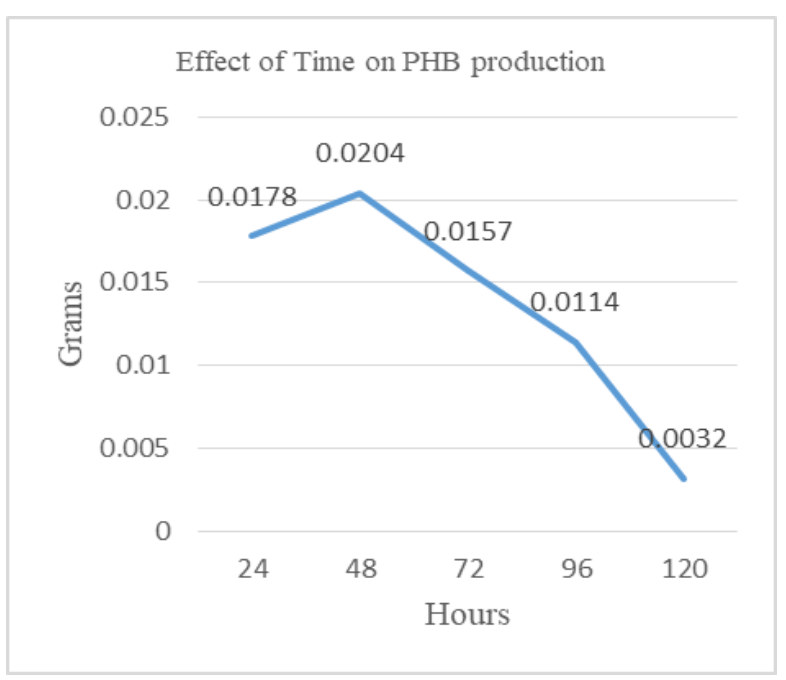

Fig. 8 : Effect of time on PHB production

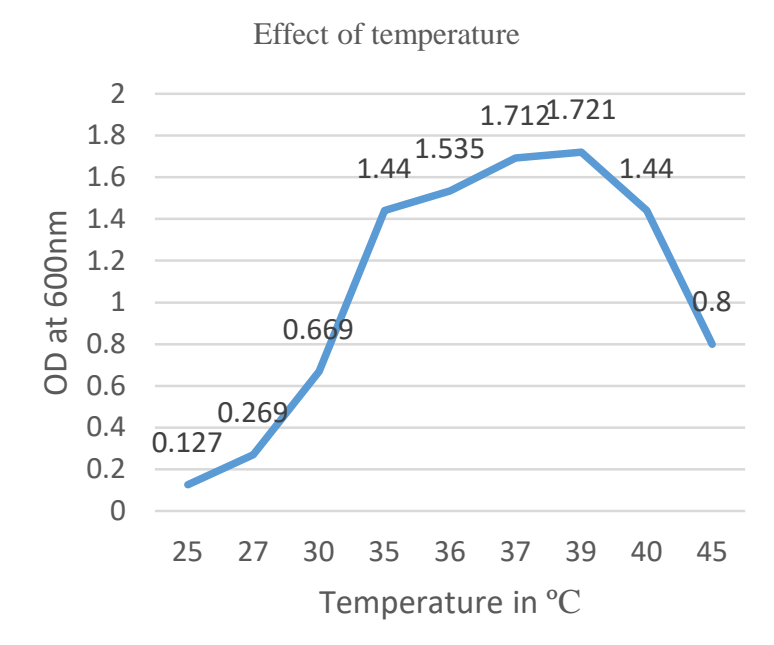

Fig. 9 : Effect of temperature on $\mathrm{PHB}$ production

\section{CONCLUSION}

Halophiles are organisms that thrive in high salt concentrations. They are a type of extremophile organisms. Halophiles can be found anywhere with a concentration of salt five times greater than the salt concentration of the ocean. Biodegradable plastics are plastics that are decomposed by the action of living organisms, using bacteria. Biodegradable plastic is a renewable biopolymer synthesized in bacteria having similar characteristics of plastics produced from petroleum character. PHB have attracted increasing attention due to their biodegradable, biocompatible, thermoplastic features, composted and burned without producing toxic by- products and be used as packaging and biomedical materials.

In the current study the production of PHB was carried out from preisolated halophilic bacteria using the production medium. Three strains out of ten showed ability to produce PHB. The extraction of PHB was carried out using chloroform extraction method. Estimation of PHB was done by using UV spectroscopy and FTIR. Optimization of different parameters was carried out for the better production of PHB.

Hydrolytic degradation occurs by surface erosion which makes PHB an attractive material for controlled release applications. Release of low molecular weight drugs from PHB tends to proceed by penetration of water and pore formation, at least above loadings of approximately 5\% drug. Release from such matrices is predominantly independent of polymer erosion; though at lower loadings it is possible to trap drug more effectively. PHB and $\mathrm{P}(\mathrm{HB}-\mathrm{HV})$ matrices lose mass very slowly when compared to bulk-degrading poly(lactide-glycolide) systems.

Currently the PHB types polyester has been employed for medical applications such as sutures, implants, urological stents, neutral- and cardiovascular- tissue engineering, facture fixation, treatment of narcolepsy and alcohol addiction, drug delivery vehicles, cell microencapsulation, support of hypophyseal cells, or as precursor of molecules with anti-rheumatic, analgesics radiopotentiator, chemopreventive, antihelminthic or anti-tumoral properties.

Identification of novel potent halophilic strains producing $\mathrm{PHB}$ by molecular characterization, the detailed molecular and structural analysis of PHB produced by extreme halo tolerant bacteria can contribute to its urgent need in replacing 
conventional hazardous plastic, playing a pivotal role in safeguarding the environment and its tremendous applications in pharma and medical sciences with the advent of biotechnology and bioinformatics.

\section{REFERENCES}

[1] Alias Z, Tan LKP (2005) isolation of palm oilutilizing, polyhydroxyalkanotes (PHA)producing bacteria by an enrichment technique. BioresourTechnol 96:1229-1234.

Doi:10.1016/j.biortech.2004.10.012.

[2] Anderson,A.J. and Dawses, E.A. (1990), Occerance, metabolism, metabolic role and industrial uses of bacteria polyhydroxyalkanoates. Microbial Rev.,54,450-

[3] Anton, J.; Rossello-Mora, R.; Rodriguez-Valera, F.; Amann, R. (2000). "Extremely halophilic bacteria in crystallizer ponds from solar salterns". Applied and Environmental Microbiology. 66: 3052-3057. doi:10.1128/aem.66.7.3052-3057.2000. PMC 92110 Freely accessible. PMID 10877805.

[4] Anton, J.; Llobet-Brossa, E.; Rodriguez-Valera, F.; Amann, R. (1999). "Fluorescence in situ hybridization analysis of the prokaryotic community inhabiting crystallizer ponds". Environmental Microbiology. 1: 517-523. doi:10.1046/j.1462-2920.1999.00065.x.

[5] Byrom D.(1987). Polymer synthesis by microorganism: technology and economics.

[6] Casamayor, E.O.; Massana, R.; Benlloch, S.; Ovreas, L.; Diez, B.; Goddard, V.J.; Gasol, J.M.; Joint, I.; Rodriguez-Valera, F.; Pedros-Alio, C. (2002). "Changes in archaeal, bacterial and eukaryal assemblages along a salinity gradient by comparison of genetic fingerprinting methods in a multipond solar saltern". Environmental Microbiology. 4: 338-348. doi:10.1046/j.14622920.2002.00297.x.

[7] Cavicchioli, R. \& Thomas, T. 2000. Extremophiles. In: J. Lederberg. (ed.)
Encyclopedia of Microbiology, Second Edition, Vol. 2, pp. 317-337. Academic Press, San Diego.

[8] Chen $\mathrm{G}, \mathrm{Wu} \mathrm{Q}$. The application of polyhydroxyalkanoates as tissue engineering materials. Biomaterials. 2005;26:6565-6578. [PubMed]

[9] Choi, G.Q.jJ.and Lee, S.Y.(1999), Factors affecting the economics of polyhydroxyalkanoate production by bacterial fermentation ApplMicrobiol Biotechnology,51, 13-21.

[10] Dworkin, Martin; Falkow, Stanley (13 July 2006). The Prokaryotes: Vol. 1: Symbiotic Associations, Biotechnology, Applied Microbiology. Springer. p. 94. ISBN 978-0-38725476-0.

[11] Erb, Tobias J.; Kiefer, Patrick; Hattendorf, Bodo; Günther, Detlef; Vorholt, Julia A. (8 July 2012). "GFAJ-1 Is an Arsenate-Resistant, PhosphateDependent Organism". Science. 337 (6093): 467$70 . \quad$ Bibcode:2012Sci...337..467E. doi:10.1126/science.1218455. PMID 22773139. Retrieved 10 July 2012.

[12] Fernandez D, Rodriguez E, Bassas M, Solanas AM, Lorens J, Marques AM, Manresa A(2005) Agro-industrial oily wastes as substrate for PHA production by the new strain Pseudomonas aeruginosa NCIB 40045: Effect of culture condition. BiochemEng j 26:159-167. Doi :10.1016/j.bej.2005.04.022.

[13] Gutierrez, M.C.; Kamekura, M.; Holmes, M.L.; Dyall-Smith, M.L.; Ventosa, A. (December 2002). "Taxonomic characterisation of Haloferax sp. ("H. alicantei") strain Aa 2.2: description of Haloferaxlucentensis sp. nov". Extremophiles. 6 (6): 479-83. doi:10.1007/s00792-002-0282-7.

[14] Kastritis, P.L.; Papandreou, N.C.; Hamodrakas, S.J. (2007). "Haloadaptation: insights from comparative modeling studies of halophilic archaeal DHFRs". Int J Biol Mac. 41 (4): 447-453. doi:10.1016/j.ijbiomac.2007.06.005. 
[15] Khanafari, A., Khavarinejad, D., Mashinchian, A. Solar salt lake as natural environmental source for extraction halophilic pigments. Iranian J. Microbiol., 2010; 2(2): 103-109.

[16] "Mars Exploration Rover Launches - Press kit" (PDF). NASA. June 2003. Retrieved 14 July 2009.

[17] Ollivier, B.; Caumette, P.; Garcia, J-L.; Mah, R. (1994). "Anaerobic bacteria from hypersaline environments". Microbiological Reviews. 58 (1): 27-38. PMC 372951 Freely accessible. PMID 8177169 .

[18] Oren, A (2002). "Diversity of halophilic microorganisms: Environments, phylogeny, physiology and applications". Journal of Industrial Microbiology \& Biotechnology. 28: 56-63. doi:10.1038/sj/jim/7000176.

[19] Oren, A. (2002) Molecular ecology of extremely halophilic Archaea and Bacteria. FEMS Microbiology Ecology: 1-7.

[20] Paul, S.; Bag, S.K.; Das, S.; Harvill, E.T.; Dutta, C. (2008). "Molecular Signature of Hypersaline Adaptation: Insights from Genome and Proteome Composition of Halophilic Prokaryotes". Genome Biology. 9: R70. doi:10.1186/gb-2008-9-4-r70.

[21] Philip S, Keshavarz T, Roy I. Polyhydroxyalkanoates: biodegradable polymers with a range of applications. J. Chem. Technol. Biotechnol. 2007;82:233-247

[22] Reaves, Marshall Louis; Sinha, Sunita; Rabinowitz, Joshua D.; Kruglyak, Leonid; Redfield, Rosemary J. (8 July 2012). "Absence of Detectable Arsenate in DNA from ArsenateGrown GFAJ-1 Cells". Science. 337 (6093): 4703. arXiv:1201.6643 Freely accessible. Bibcode:2012Sci...337..470R. doi:10.1126/science.1219861. PMC 3845625 Freely accessible. PMID 22773140. Retrieved 10 July 2012.

[23] Reed, Christopher J.; Lewis, Hunter; Trejo, Eric; Winston, Vern; Evilia, Caryn (2013). "Protein
Adaptations in Archaeal Extremophiles". Archaea. pp. 1-14. doi:10.1155/2013/373275.

[24] Rehm BHA. Polyester synthases: natural catalysts for plastics. Biochem. J. 2003;376:15-33. [PMC free article] [PubMed]

[25] Rodríguez-Contreras A, Koller M, Miranda-de Sousa Dias M, Calafell-Monfort M, Braunegg G, Marqués-Calvo MS. High production of poly 3-hydroxybutyrate from a wild Bacillus megaterium Bolivian strain. J ApplMicrobiol 2013 May 1;114(5):1378-87.

[26] Saidu M Bashir1, Madhuri Girdhar1, Hasibur Rehman2 and Anand Mohan1: Polyhydroxybutyrate (PHB) Production and Mutagenesis of Halophile isolates from the East African Rift Salt Lake 1Department of Biotechnology, Lovely Professional University, Phagwara, Punjab, India. 2Department of Biology Faculty of Sciences University of Tabuk,Tabuk Kingdom of Saudi Arabia (KSA).

[27] Santos, H.; da Costa, M.S. (2002). "Compatible solutes of organisms that live in hot saline environments". Environmental Microbiology. 4: 501-509. doi:10.1046/j.1462-2920.2002.00335.x.

[28] Steinbüchel A, Füchtenbush B. Bacterial and other biological systems for polyester production. Trends. Biotechnol. 1998;16:419427. [PubMed] 